\title{
TRADITIONAL ECOLOGICAL KNOWLEDGE AND INDIGENOUS FOODWAYS IN THE ANDES OF PERU
}

\section{INTRODUCTION}

Indigenous communities around the world continue to develop effective solutions to global food challenges, revitalizing traditional knowledge in biodiversity preservation and enacting food sovereignty practices that enable people and societies to feed themselves (Holt Giménez and Shattuck; Desmarais; Shiva). TEK refers to the accumulative body of knowledge, including skills, practices, and innovations (technology), which is often derived from Indigenous peoples' intimate interactions with their traditional environment.

Early empirical studies of Indigenous peoples' TEK in agricultural systems have been widely documented, for example, the pioneering work of Harold Conklin (1957), who studied the horticultural practices of the Hanunóo people of the Philippines and recorded detailed information about local plants (totalling up to 1,600 plant species). TEK began to gain to notoriety in the 1980 s among various multidisciplinary fields of study, such as the environmental sciences, particularly in ecology. At present, TEK is considered an interdisciplinary theory drawing from social and cultural anthropology, biology, ecology, and resource management fields such as fisheries, wildlife and forestry (Berkes, Folke, and Colding; McGregor).

Yet, mainstream Food Security development and policy-making interventions do not always draw from TEK, and place greater emphasis on scientific and high-tech agricultural approaches to address Food Security (Bello and Baviera; Holt Giménez and Shat- 
tuck; Altieri and Toledo). 'Food Security' is a modern term adopted to express national and international goals of supplying adequate amounts of food for a given population. According to a definition provided by the World Food Summit in 1996, Food Security is achieved "when all people, at all times, have physical and economic access to sufficient, safe, and nutritious food to meet their dietary needs and food preferences for an active and healthy life" (United Nations Food and Agriculture Organization (FAO).

Despite the aim of working towards eradicating food scarcity, the concept of Food Security has been criticized by Indigenous organizations, food studies, and environmental scholars for the narrowness of its scope. This body of scholarship (see, for example, (De Schutter; Desmarais; Holt Giménez and Shattuck; McMichael) argues that Food Security is often centred on the availability ${ }^{1}$ side of the equation endorsed by technology-intensive monoculture farming, and the adoption of scientific-technological systems, as in the case of Cenetically Modified Organisms (GMOs).

These industrial and technical approaches to Food Security are being challenged by concerns about the safety and nutritional value of food, and the long-term sustainability of the environment. The latter not only threatens the well-being of Indigenous peoples, who rely heavily on healthy ecosystems for their food sustenance, but ultimately of people everywhere (La Vía Campesina; Shiva; Wittman, Wiebe, and Desmarais). In this work,

Indigenous Social Movements in the Americas I seek to build on the growing body of scholarship addressing the diversity and complexity of TEK in sustainable food systems, and on the multivalent human-nature relationship of Indigenous peoples for safeguarding Food Security. In doing so, I am centering the discussion on Indigenous cosmovisions and referring to distinctive Indigenous ways of life and knowledge that, are vital for the continuance of Indigenous foodways. In this study Indigenous foodways denotes not only knowledge and practices concerning the plant species and animals found within peoples' territories, but also a rich cultural component embodied in stories,

1. The notion of availability within the Food Security contexts suggests that there is enough availability of inputs (seeds, water, and land) and appropriate quality of food for people to be supplied through domestic production or imports (Timmer 2015). 
songs, recipes, and practices that complement traditional foodways. I focus on cosmovision to highlight the challenges that Quechua people have faced through the colonial legacy in their efforts to preserve their foodways and ways of knowing. This specifically includes capitalism, which disrupts subsistence economies by imposing the capitalist ideology that natural resources are vehicles for profit, and land is there to be exploited solely for economic purposes (Maxwell; Paarlberg).

The study partners cited throughout this paper are Quechua holders of knowledge ${ }^{2}$ concerning foodways practices, agricultural production, and cultural traditions associated with native food systems, such as planting rituals and ceremonies. Case studies with community partners in Choquecancha and Rosaspata in the highlands of Peru were conducted between March 2016 and August 2018. Utilizing a participatory action research approach, primary data was collected through talking circles, oral stories, and dialogues with knowledge holders who ranged from elders, community leaders, and people engaged in traditional food systems. Empirical data was analysed using TEK theory, which studies Indigenous peoples' knowledge systems embedded in their cosmovisions (Battiste; Berkes; Cajete). The research draws from secondary data, which enabled cross-checking of sources and extended discussions on empirical data.

In this study, I do not claim to speak for the Quechua people, but rather draw on their ways of knowing and being, which were generously shared by each of them, and from the knowledge I attained from my kinship relations and lived cultural experiences as an Indigenous woman of Peru. To provide a foundation for the research reported herein, I provide conceptual background on cosmovision, Indigenous foodways, and TEK theory. Subsequently, I present the research methodology, methods, results and discussion of findings followed by the conclusion drawn from this study.

2. In this paper, I use the term "knowledge holders" to denote Quechua people who have extensive knowledge on the study topics and who are authorities in their community. This term does not exclude people who may not be of the age of an Elder but who are important thinkers and leaders within the Andean world. 
I refer to Andean cosmovision as holistic ways of knowing (epistemology) and being (ontology), bestowed on them by their ancestors and endowed to them by nature, encompassing economic, social-political and cultural knowledge systems (Apffel-Marglin; Marglin; Lajo). Gonzales and Conzales (2010) offer valuable insights into the unique epistemological viewpoint of the Andean people below:

In the Andean world, los saberes (knowing) is a result of the here and now, of living in conversation with and between everyone and everything. Conversing and cultivating are not the exclusive privilege of the human collective. Andean Indigenous culture is one of nurturance through a flowing and continual conversation among the three collectivities that comprise the local pacha. These three collectivities cultivate ayllu (natural collectivity) [...]. Knowing is dependent on what takes place in each chacra, ${ }^{3}$ where specific saberes are given (Gonzales and Gonzales 93).

The above quote suggests that Quechua cosmovision is based on experiential learning of means of perceiving and interacting with the environment through mutually-supportive relationships between humans and non-humans (rivers, mountains, lakes etc.) residing on Pachamama (Mother Earth in Quechua language). Such experiential learning and a holistic relationship with the land have enabled Quechua people living in severe weather conditions to gain

Indigenous Social Movements in the Americas agricultural knowledge to develop varied and locally-adapted farming systems. For instance, the large-scale irrigation system of canals built by Quechua peasants to divert water from rivers descending from highland areas to irrigate foothill slopes are clear examples of a sustainable traditional farming system (Altieri and Toledo).

I refer to Indigenous foodways as the distinctive ways of growing, preparing, storing, and sharing foods such as edible plants, food crops, and animals by Indigenous peoples within a geographic area, and the way they preserve such foodways through cultural principles such as respect, reciprocity, and biological sensibility,

3. Chacra refers to small plots of land allotted to individual families. In the Andean world a chacra is understood not only as a small plot of land, but as a sacred space for the nurturing and flourishing of all forms of life (Field research notes in the Andes, September 2016). 
among other values. In this sense, Indigenous foodways are the opposite of mechanized industrial agricultural systems, which make use of chemicals or pesticides and rely on hybrid or GMO varieties of the world's major food staples to tackle food challenges. Indigenous foodways are found in every region of the world; for example, for Pacific Northwest tribes the wild salmon holds cultural and spiritual value, and for the Māori of Aotearoa New Zealand, the kūmara (sweet potato) is regarded as a sacred food. All these Indigenous foods are collected, hunted or fished locally based on in-depth and locally rooted knowledge-TEK, which is unique to every Indigenous group, as described below.

\section{TEK THEORY}

TEK is based on Indigenous peoples' relationships with the natural world, and their ability to provide comprehensive insights into nature and information about natural phenomena. There is no universally accepted definition of TEK in academic literature, but the predominant conceptualization of TEK comes from Western scholarship (LaDuke; Berkes; Pierotti and Wildcat; McGregor). From a Western perspective, TEK is defined as an enduring 'backdrop body of knowledge' that has been acquired mostly through oral history from one generation to the other over thousands of years (Berkes; Agrawal).

However, Indigenous scholars disagree with the Western view of TEK used to denote their knowledge systems. They argue that traditional knowledge is place-based and therefore cannot be confined to a particular source of knowledge (Battiste; Cajete; Deloria; McGregor). Indigenous scholar McGregor eloquently points out the reason for such disagreement and argues that "to understand where TEK comes from one must start with Indigenous people and our own understanding of the world" (386).

This study supports the Indigenous view of TEK, and argues that Quechua peoples have their own TEK, reflecting an Andean cosmovision, described in the results section of this study. Consequently, analysis of empirical evidence is made through the lens of TEK theory and adopts a participatory action research approach and involves Indigenous research methods as described below. 
Indigenous scholars (Kovach; Pihama, Cram, and Walker; Smith; Wilson) argue that Indigenous peoples have distinctive forms of constructing, validating, and acquiring knowledge. For example, language plays a key role in articulating Indigenous peoples' understanding of the world as well as their transmission of knowledge, which they predominately share through oral histories (Battiste; Cajete). Considering the nature of this Indigenous-based investigation, it was prudent to privilege Indigenous ways of acquiring, sharing, and valuing knowledge in this study. Therefore, this investigation adopted a community-based participatory action research approach; for example, before beginning to gather empirical data, I met with community leaders from the study communities to discuss and refine the research questions, and subsequently to translate them into Spanish, and into English when required. Also, oral interviews and talking circles were organised and facilitated by knowledge holders and myself. Community study partners thus took on an active role during the research process by being fully and actively engaged in the research from the beginning till the end of the project.

\section{RESEARCH LOCATION AND METHODS}

The empirical research was carried out in Peru between March 2016 and August 2018. The Quechua community partners who

Indigenous Social Movements in the Americas took part in my research in Peru were from Rosaspata and Choquecancha. The Quechua people are an Indigenous people of South America. There are approximately 3.5 million Quechua people in Peru, predominantly living in the Andean region (Espinoza). These Quechua communities are nestled high in the southern Andes, and the primary form of subsistence in these Quechua communities is traditional agriculture. For centuries Quechua farmers have made use of their Indigenous agricultural heritage to develop varied and locally adapted farming systems. This agricultural knowledge has enabled them to acquire community Food Security and conserve agro-biodiversity (Altieri; Apffel-Marglin).

Thirty oral history interviews were conducted with knowledge holders, including Quechua elders, farmers, and wild food foragers. In these interviews, complemented with two talking circles 
with female farmers, gatherings with Indigenous community leaders and local agroecologists, and spontaneous storytelling sessions with elders, the participants all shared diverse stories of native foodways, biodiversity preservation, and cultural knowledge and practices.
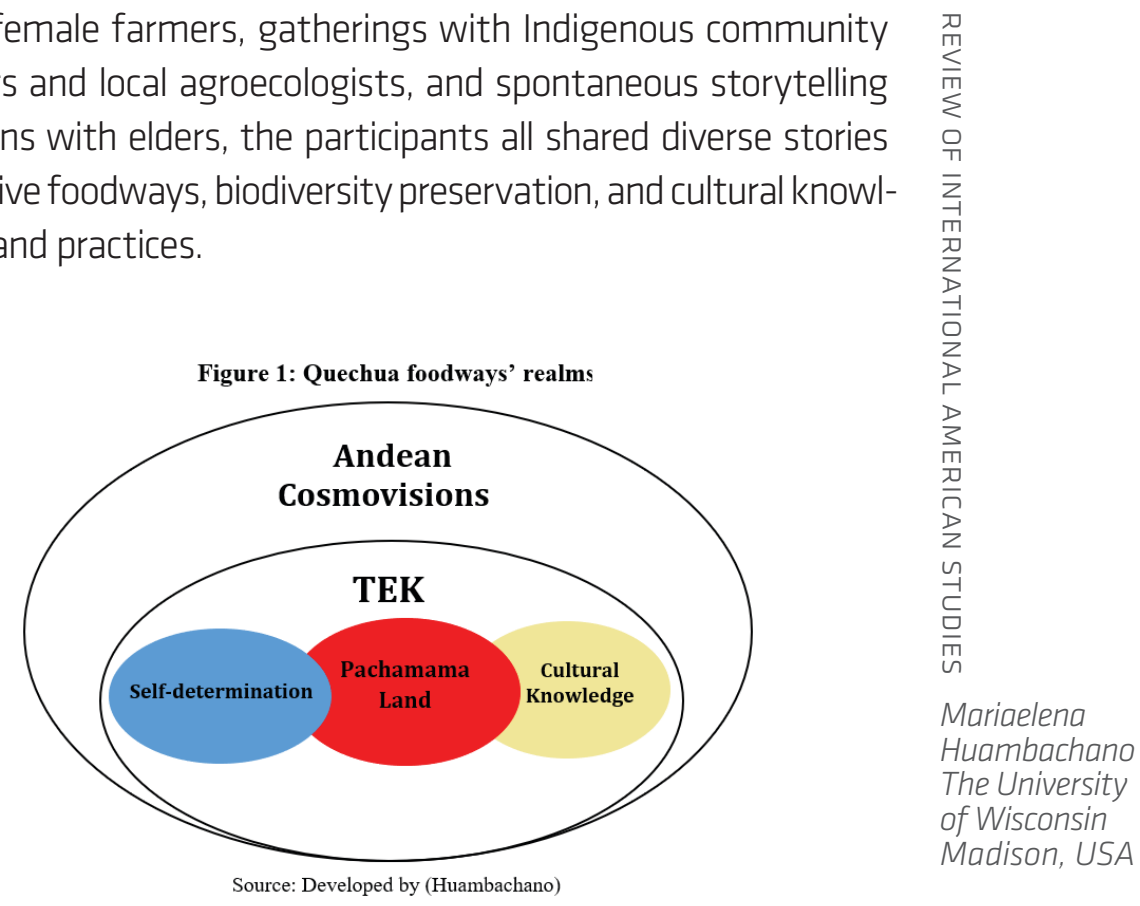

RESULTS AND DISCUSSION

This study suggests that it is in the uniqueness of Quechua peoples' TEKs that the foundation of an Indigenous-based theoretical model of food sovereignty rests, grounded on three interrelated pillars: land, self-determination and cultural knowledge, although this contests the current discursive global Food Security approach (Figure 1). These three interconnected realms enable the Quechua to safeguard their Food Security, and to do so without compromising their beliefs, TEK, or value systems. I will now provide a description complemented with narratives on how each interconnected realm pervades and infuses Quechua peoples' foodways.

INDIGENOUS WAYS OF LIVING: PACHAMAMA-LAND

A recurrent theme throughout this research has been the understanding of the land for Quechua people as Mother Earth-Pachamama. As stated by Petronila, a Quechua leader from Choquecancha: 
Pachamama is my mother, I consider myself the offspring of Pachamama because she is like a mother who feeds us with so many foods. In gratitude, I sing and dance for her every day in my chacra. Here in this community, we value and respect Pachamama very much because without seeds we would not have anything to eat. For that reason, I feel like the offspring of Pachamama, and as a daughter I hold responsibilities to preserve the well-being of Pachamama and all my other relativesthe apus (mountains) and lakes to be able to continue with the legacy of my ancestors and preserve our seeds and well-being. ${ }^{4}$

Petronila's narrative clearly reflects distinctive Indigenous ways of living centered on the understanding that runas (humans) do not define a divisible unity between humans and nature because everything is interrelated in the streams of life. For Quechua people, humans are intrinsically intertwined with nature, and the practice of reciprocal relations of living together generates unique wisdom about plants, animals, and other native components of nature such as water and climate systems. Thus, Quechua peoples' ways of life are based on a kinship-centric system wherein all community members humans and non-humans, including Andean deities, or wacas (in Quechua language), have duties and responsibilities to respect and nurture one another.

Quechua communities' way of living is hindered by the dominant Western paradigm of nature, which sees the environment as existing independently from humans. This Western perspective is exemplified when a researcher detaches from the object of study,

Indigenous Social Movements in the Americas in this case, nature. This is done because nature as an object is subjected to a systematic, fragmented and analytical methodological approach in the knowledge creation process. Another example is monoculture agriculture wherein seeds are reduced to a raw input for agribusiness. These examples highlight a rational and controlling approach to nature that views it solely in terms of economic exploitation.

In stark contrast to Western ideology are Indigenous cosmovisions, which embody a holistic and spiritual-cultural approach between humans and nature underpinned by the ethical principles of reciprocity, respect, and interrelationality between all community members residing in a given territory (Lajo 2011, Huambachano 2018).

4. Petronila Quispe, personal interview December 2017. 
A Peruvian scholar (Lajo) describes three principles underpinning the ethical and customary laws of Quechua people with nature:

Allin Ruay: Means 'do good deeds' through ethical behaviour at all times.

Munay Allin: Expresses the view that to live in harmony with Pachamama humans ought to deeply respect, care, and love all other non-human relatives.

Allin Yachay: This principle refers to thinking wisely or to be a wise person to ensure social fairness within communities (Lajo 2).

This study adds value to Lajo's theorization of Quechua ethical and customary laws by providing examples on how spiritual practices (rituals) symbolise Quechua people's moral responsibilities with their kinship system. As Andali of the community of Rosaspata pointed out, "I learnt especially from my mum and grandmother to always give thanks to Pachamama, and every August is a special month because we have many festivals honouring Pachamama." ${ }^{5}$ Andali's narrative is an example of Quechua farmers being respectful of Pachamama because she provides them with resources for their food sustenance, and in reciprocity they express their gratitude through cultural and spiritual practises.

The set of Indigenous customary laws, ethical principles and kinship governing structures is what Daigle (2019) describes as the Indigenous political and legal orders that frames Indigenous forms of authority and governance. Similar Indigenous political, legal and cultural traditions are found in other Indigenous groups, as described in the book All Our Relations: Native Struggles For land and Life (LaDuke 2017), which suggests that what links Indigenous societies around the world are practices related to the two main tenets below:

a) Reciprocity, which plays a key role in defining the ethical behaviours between humans and nonhumans within natural law. Indigenous peoples believe that non-humans deserve an appropriate ethical approach encompassing the values of respect and gratitude, as well as a political approach including

5. Andali Huayta, personal interview, August 2018. 
norms and structures concerning their actions and behaviour towards non-humans lives.

b) Cyclical thinking that acknowledges that the world flows in cycles, and therefore, there is no beginning nor end and what one does today (birth) will affect one in the future (rebirth).

Reciprocity and cyclical thinking are found in the TEK of various Indigenous societies, for example, in North America, the Anishinaabeg people, and in South America, the Andean people. To illustrate the reciprocity tenet of Indigenous peoples of North America, Berkes explains that:

A hunter always speaks as if the animals are in control of the hunt. The success of the hunt depends on the animals; the hunter is successful if the animal decides to make himself available. The hunters have no power over the game, animals have the last say as to whether they will be caught (Berkes 107).

In this illustration, the fish is considered by Indigenous peoples to be a person too, and it is assumed that it is has the intellectual capacity to identify the danger of being hunted. Therefore, if the fish was to be caught, it can also be assumed that this was its own decision (LaDuke); hence, the metaphor of the prey 'giving itself to you' is useful in understanding the concept of gratitude from the fish who gifted its life to the hunter, as well as the hunter

Indigenous Social Movements in the Americas honouring the death of the fish or other non-human life (Berkes).

The value of gratitude for the bounties of Pachamama to them is expressed by Quechua communities in the form of food ceremonies and rituals. The month of August holds special significance for the Quechua people because it is believed that Pachamama is most fertile during August. I was fortunate to experience a few festivities in August, during which I witnessed male llamas and alpacas being blessed on the first day of August, ceremonial offerings being made in the form of coca leaves, corn, and fruits being brought not only to Pachamama but also to other deities, such as the apus (sacred mountains), mayu (rivers), and qochas (lakes). Another example is the ritual performed by the Andean people called 'Inti Raymi' (Festival of the sun), characterised by the sharing of food within and across all Quechua communi- 
ties to express gratitude to the god 'Inti' (sun) for the fertility of the land and an abundant harvest season (Espinoza; Marglin).

Since time immemorial, not only Quechua people but also other Indigenous peoples have honoured this cultural-food relation in the form of food ceremonies to convey appreciation, love and respect to their non-human kin (the sun, water, animals, and plants) (Marglin; Rostworowski de Diez Canseco; McGregor). For example, Objiwe scholar LaDuke explains that the Objiwe or Anishinaabeg people of North America were gifted with manoomin (wild rice). ${ }^{6}$ Therefore, Ojibwe people express gratitude for the bounties of Shkaakaamikwe (Mother Earth) with large thanksgiving feasts for the first manoomin of the season. Potawatomi scholar Kyle Whyte defines this cultural-food relation as 'collective food relations' and goes on to describe it as to the value of food and the self-determination of human groups, such as urban communities of colour and Indigenous peoples, among many other groups, to govern their political, cultural, and legal food systems (Whyte).

Indigenous peoples' collective food relations are now being disrupted by neoliberal capitalism, and a clear example of such human-nature disruption is the current global Food Security model characterized by the commercialisation and industrialisation of food systems, with a few food corporations gaining monopoly control over food systems (Bernstein; Borras, Saturnino). This process undermines traditional food systems and Indigenous peoples' capacity for autonomy and self-determination (Borras, Saturnino; Desmarais; La Vía Campesina).

\section{SELF-DETERMINATION AND LAND RIGHTS}

Peru is a signatory to a series of international law instruments in support of the rights of Indigenous peoples, such as the United Nations Declaration of the Rights of Indigenous Peoples. This Declaration is considered one of the most significant milestones achieved by Indigenous peoples because it sets the international standards for the recognition of Indigenous peoples as a stand-alone group

6. A grain that predominantly grows in lakes and rivers in the central part of North America (LaDuke 2017). 
within a nation (United Nations Department of Economic and Social Affairs [UNDESA]). The right to self-determination of Indigenous peoples is explicitly referred to in Article 3 of the United Nations Declaration on the Rights of Indigenous peoples, which defines them as follows:

Indigenous peoples have the right to self-determination. By virtue of that right they freely determine their political status and freely pursue their economic, social and cultural development" (UNDESA).

To understand the Indigenous conception of self-determination, it is prudent to explain that it refers to Indigenous peoples' collective rights to govern social-political, cultural, and economic institutions within their territories rooted on Indigenous cosmovision for the respect, nurturing, and preservation of the land-Mother Earth (Lajo, 2011, Apffel-Marglin, Whyte, 2016). Collective sovereignty rights generally entail collective ancestral rights to land and resources, including where applicable, families, clans, homelands, and communities as well, as the natural world that challenge the economic and political interests of dominant colonial powers, such as capitalism (Gibbs; Apffel-Marglin; Fernard).

Quechua communities have a long tradition of communal governance land system referred to as ayllu that have enabled them to safeguard their foodways, this tradition includes a sector

Indigenous Social Movements in the Americas of land that is operated communally alongside chacras or small plots allotted to individual families, and there is an ayllu leader chosen by all ayllu members (Apffel-Marglin; Mayer). As one study partnered Tito Huamani expressed: "Ayllu is our ancestral governance and political system. As a community we all have individual and share responsibilities with all three worlds: natural, human and spiritual dimensions, because we are all interconnected, and to live in harmony we ought to respect and love one another."7 Thus, the ayllu system reflects Quechua communities' collective rights to self-govern their territories according to their cultural, political, and legal traditions, which form the basis for Indigenous

7. Tito Huamani, personal interview, September 2016. 
governance. Quechua people the land rights landscape poses challenges in terms of access to land for food production

Indigenous peoples of Peru have limited legal recognition, except for native communities legally recognised in the Peruvian Constitution under the decree 89 (Furnish 103). For Quechua people the land rights landscape poses challenges in terms of access to land for food production and ultimately suppresses their 'collective sovereignty rights,' as this study suggests. As one Quechua study partner stated, "I am in fear that the government will come here one day and change our ancestral land system, and so my land will be given to big food corporations who will hurt my mother (Pachamama) by exploiting the land all year round without having any kind of consideration for her well-being." 8 Thus, it can be argued that for Quechua people to be food sovereign, they need to have control over land, resources, and cultural knowledge, and if they lose their land and all resources wherein, that means they lose agency over their food systems and cultural identity. The next section focuses on the link between TEK and cultural knowledge for safeguarding Indigenous foodways.

\section{CULTURAL KNOWLEDGE AND TEK}

In this study, cultural knowledge refers to customary laws, values, and agricultural practices that are unique to Quechua people and rooted in their TEKs. The TEK of Quechua people is referred to as Yachay (saberes in Spanish and knowing in English) and plays a crucial role in Quechua peoples' ways of knowing, especially for agricultural and biodiversity preservation forming the basis for the often-overlooked relationship between cultural knowledge and TEK. The book entitled Native Science, Natural Laws of Interdependence by Native scholar Gregory Cajete provides insights into the fundamental values and methodological approaches of Native science. In it Cajete states that:

Native science is a broad term that can include metaphysics and philosophy; art and architecture; practical technologies and agriculture; and ritual and ceremony practised by Indigenous peoples both past and present. More specifically, Native science encompasses such areas

8. Sonia Quispe, personal interview, September 2017 
as astronomy, farming, plant domestication, plant medicine, animal husbandry, hunting, fishing, metallurgy, and geology-in brief, studies related to plants, animals, and natural phenomena. Yet Native science extends to include spirituality, community, creativity, and technologies that sustain environments and support essential aspects of human life (Cajete 3).

In the statement above, Cajete argues that a distinctive Native science has its basis in the relational worldview of Indigenous knowledge; it is, he says, about "honouring the primacy of direct experience, interconnectedness, relationships, holism, quality and value" (66). An example of Native science is when I observed that, Quechua farmers forecast weather seasons for agricultural production by observing the Pleiades star cluster as stated by the elder Suni: "In February, our elders gather around to observe when the Willkawara (Sacred Star) constellation comes up in the sky. Also, if the stars are very bright, then it is going to be a wet year, but if the stars are opaque then it is going to be a dry year." Suni further added that, I remember my grandmother telling me about the myth of the Willkawara. It is a star that protects our crops."

In this narrative, Suni is referring to the comprehensive astrological knowledge of Quechua people, which is imperative to guiding their agricultural system. For example, in the Andean world, when the Willkawara appears at its zenith at nightfall on the autumn equinox (March 21), this symbolises the beginning of a good harvest season. Andean biodiversity and the cultural and spiritual

Indigenous Social Movements in the Americas meaning that this various life forms such as corn and potatoes hold for them defines distinctive characteristics of its agricultural landscape. The Quechua people inherited in-depth agricultural knowledge from their ancestors, the Incas, who were master agriculturalist and experts in the domestication of crop species (Altieri; Brush; Mayer).

For example, Inca scientists experimented with seeds to determine which plants are more resilient to the extreme weather conditions of the highlands to ensure biological agricultural preservation. The Inca people domesticated approximately seventy crops species for maintaining the diversity and sanctity of plants for their food survival (Brush). Knowledge holders Sonia Quispe

9. Suni Carhuancho, personal interview, September 2017. 
and Maria Tinto of Choquecancha enthusiastically acknowledged the biodiversity of their crops with the statement: "We grow more than fifty varieties of corn here in Choquecancha." ${ }^{10}$ Peru a country with one of the highest levels of biodiversity in the world; for example, Andean biodiversity includes over 2,500 varieties of potatoes, as well as other valuable Andean crops, such as corn, tubers such as uqa ${ }^{11}$ and quinua, ${ }^{12}$ and root crops like maca ${ }^{13}$ (Altieri and Toledo; Brush; Marglin).

The Quechua peoples' food systems as seen through a TEK lens denote a profound reciprocal connection with all human and non-human relations residing on Pachamama. The value of food for Quechua people has an intangible value, because the notion of food-rather it holds cultural meaning it represents the continuance presence and teachings from their own cultural and spiritual ancestors such as apus (sacred mountains). Nevertheless, agri-food business, ${ }^{14}$ predominantly from Europe and North America has taken the lead in the ongoing transformation of agriculture and food production globally. A case in point, are Quechua peoples' agricultural biodiversity and traditional livelihoods that are fundamental to their well-being, which are now endangered by the spread of monoculture agriculture and genetically modified organisms (CMOs) that disrupts their holistic and reciprocal relationship with nature and non-human relations (Bello and Baviera; FAO; Holt Giménez and Shattuck).

\section{INDIGENOUS FOOD SOVEREIGNTY}

In this study Quechua peoples as a collective decide how, where, and by whom food is to be produced through the ayllu system and exercise cultural traditions and spiritual practices inherent to their cultures and ways of knowing associated with food, which

10. Sonia Quispe and Maria Tinto, personal interview, September 2017.

11. Uqa in Quechua and Oca in Spanish is a yellow and purple tuber that grows in the Andean highlands.

12. This crop has high nutritional value since its high protein content is higher than wheat or rice (Marglin).

13. Maca is a root crop that has its origins in the highlands of Peru; it is relatedly unknown in the food academic literature despite its high levels of proteins. It is also used as medicinal herb (Altieri).

14. Businesses in the agricultural and food industries (McMichael). 
reverberates with the notion of food sovereignty. According to one prominent definition, food sovereignty is "the right of peoples and governments to choose the way food is produced and consumed in order to respect livelihoods" (La Vía Campesina). La Vía Campesina, an international organisation of Indigenous farmers, peasants, small producers, and farm workers, initiated the food sovereignty movement in 1996 to put the control of productive resources (land, water, seeds and natural resources) in the hands of those who produce food (La Vía Campesina).

Indigenous scholars (Coté, Huambachano, Hoover, Nelson, Whyte) argue that, Indigenous food sovereignty underscores the revitalization of Indigenous food systems as a tool for reclaiming their traditional food practices and principles and moving beyond colonial approaches to Food Security. They further discuss that, Indigenous food sovereignty efforts are not only forms of resistance against colonial-capitalist legacies, but also a resurgence of Indigenous epistemologies and ontologies encompassing Indigenous cultural (e.g. kinship relations), political (e.g. governance structures), legal (e.g. authority status of non-human kin) and economic (e.g. locally-based economies) institutions as part of the larger process of decolonisation and self-determination.

Indigenous peoples' food sovereignty is expressed in their self-determination to preserve and honor those human and nonhuman kin connections. In effect, Indigenous peoples around

Indigenous Social Movements in the Americas the world are insisting for their right to food sovereignty to be recognized, but what is the right to food of Indigenous peoples? It refers to the inherent right of Indigenous peoples, to have access to safe, nutritious, and culturally appropriate foods to sustain themselves and their societies (De Schutter). In Huambachano's 2018 comparative study of Quechua and Māori peoples' food sovereignty models, she concluded that culture is an important aspect in analysis of the right to food and the food sovereignty of Indigenous peoples because 'food' is indispensable to shaping Indigenous peoples' lives and Indigenous identities.

In the study by Kuhnlein, Erasmus, and Spigelski about Indigenous peoples' food systems, the authors argue that a food system retains a connection to long-evolved cultures and patterns of living in local ecosystems. Also, food systems reflect a trea- 
sure trove of knowledge that contributes to peoples' well-being and health and can benefit all humankind. This investigation resonates with the study of Kunhle et al., and adds evidence on the meaning of, self-determination, land and cultural knowledge framing the foodways model of these two Quechua communities, entrenched in their cosmovision and TEKs.

\section{CONCLUSION}

TEK reflects an Indigenous way of life, and knowledge passed down from one generation to the other in the form of foods. Indigenous ways of knowing still reverberate for Indigenous peoples from Pachamama in the Andes, Tonantzin for the Aztec and Nokomis for the Anishinaabe and Ojibwe/Chippewa tribes of North America (Kimmerer; LaDuke; Lajo). Importantly, this study found clear evidence of the value of TEK not only as a tool to gain local knowledge, but also as a collaborative concept to gain in-depth understandings of these two unique Quechua (TEK) systems concerning Food Security.

The dominant Food Security model is at odds with Indigenous foodways because it dismisses their spiritual, cultural, and physical relationship-based approach, and the 'collective food relations' they have with the land.

As a result, these two Quechua case studies call for the need to recognise customary laws and land rights of not only Quechua people, but Indigenous peoples and local communities in general, and to acknowledge Indigenous cosmovisions that conceptualizes their political, cultural and legal orders that give meaning to 'collective food relations. Collective food relations concern much more than just obtaining food for purposes of maintaining a livelihood, they represent an essential aspect of cultural identity. For example, each year activities associated with food, such as harvesting ceremonies, dances, pow wows, and communal food festivals renew the family, community, cultural, political, and social relationships that connect Indigenous peoples with all community members, including plants, rivers and spiritual beings. Furthermore, it is fundamental to consider that many Indigenous peoples view the right to food as a collective one, and are demand- 
ing their rights to sufficient, healthy, and culturally appropriate food, not just food with a calorie count value.

To conclude, Quechua communities are resisting colonial powers such as capitalism by revitalizing Indigenous foodways. The two communities discussed here continue to exercise their rights to selfdetermination, their ancestral collective rights to land, and their rights to continue practising their Indigenous cultural traditions. More importantly, these two Quechua communities are restoring the human-nature relationship that has been broken, and which continues to be disregarded by the current global Food Security model, a fact that impacts their well-being because they heavily rely on healthy ecosystems for their livelihood. Food security from an Indigenous perspective goes far beyond a legal and human rights-based approach; it emphasises the cultural food relations and responsibilities Indigenous peoples have with the natural world, as well as the efforts being undertaking by Indigenous people to assert their rights to self-determination through the revitalization of Indigenous foodways and TEK systems. 
Agrawal, Arun. "Dismantling the Divide between Indigenous and Scientific Knowledge." Development and Change, vol. 26, no. 3, 1995, pp. 413-39.

Altieri, Miguel A., and Victor Manuel Toledo. "The Agroecological Revolution in Latin America: Rescuing Nature, Ensuring Food Sovereignty and Empowering Peasants." Journal of Peasant Studies, vol. 38, no. 3, 2011 pp. 587-612.

Altieri, Miguel A. Agroecology: The Science of Sustainable Agriculture. Westview Press, 1995.

Apffel-Marglin, Frédérique. "From Fieldwork to Mutual Learning: Working with PRATEC." Environmental Values, vol. 11, no. 3, 2002, pp. 345-67.

------. The Spirit of Regeneration: Andean Culture Confronting Western Notions of Development. Zed Books, 1998.

Battiste, Marie. Indigenous Knowledge and Pedagogy in First Nations Education: A Literature Review with Recommendations. National Working Group on Education and the Minister of Indian Affairs, Indian and Northern Affairs Canada (INAC), 31 Oct. 2002, www. usask.ca/education/documents/profiles/battiste/ikp_e.pdf.

Bello, Walden, and Mara Baviera. "Food Wars." Monthly Review, vol. 61, no. 3, 2009, p. 17.

Berkes, Fikret. "Sacred Ecology, Traditional Ecological Knowledge and Resource Management." Economic Geography, vol. 76, no. 4, 2000, pp. 395-96.

Berkes, Fikret, Carl Folke, and Johan Colding. Linking Social and Ecological Systems: Management Practices and Social Mechanisms for Building Resilience. Cambridge UP, 2000.

Bernstein, Henry. 'The Peasantry' in Global Capitalism: Who, Where and Why?" Socialist Register, vol. 37, no. 37, 2009, pp. 25-49.

Borras, Saturnino M., and Marc Edelman. Political Dynamics of Transnational Agrarian Movements. Practical Action Publishing, 2016.

Borras, Saturnino. "Agrarian Change and Peasant Studies: Changes, Continuities and Challenges: An Introduction." The Journal of Peasant Studies, vol. 36, no. 1, 2009, pp. 5-31. 
Brush, Stephen B. "Farmer's Rights and Genetic Conservation in Traditional Farming Systems." World Development, vol. 20, no. 11, 1992, pp. 1617-30.

Cajete, Gregory. Native Science: Natural Laws of Independence. Clear Light Publishers, 2000.

Contreras Salinas, Sylvia. "Saber Campesino: Otra Forma De Experimentar La Escuela Rural” Estudios Pedagogicos, vol. 38, no. 1, 2012, p. 367.

Conklin, Harold C. Hanunoo agriculture. A report on an integral system of shifting cultivation in the Philippines.Vol.2. (1957).

De Schutter, O. The Right to Food and Sustainable Global Food System. Special Rapporteur on the Right to Food. 17th Session of the UN Commission on Sustainable Development. 2009, www.srfood. org/images/stories/pdf/otherdocuments/19-srrtfsubmissioncsd-01-05-09-1.pdf.

Daigle, Michelle. "Tracing the Terrain of Indigenous Food Sovereignties." The Journal of Peasant Studies, vol. 46. 2019, vol. 26, no. 2, 2019, pp. 297-15.

Deloria, V. "Indigenous Peoples." The Blackwell Companion to Religious Ethics. edited by W. Schweiker, Blackwell Publishing, 2005, pp. 552-559.

Indigenous Social Movements in the Americas

Desmarais, Annette Aurelie. "The Via Campesina: Peasant Women on the Frontiers of Food Sovereignty." Canadian Woman Studies, vol. 23, no. 1, 2003, p. 140.

Espinoza, Waldemar. Los Incas. Economía, Sociedad Y Estado En La Era Del Tahuantinsuyo. Amaru Editores, 1997.

FAO, WFP. IFAD. The State of Food Insecurity in the World 2015. Meeting the 2015 International Hunger Targets: Taking Stock of Uneven Progress. FAO, 2015.

Fernard, Braudel. Civilization and Capitalism, 15th-18th Century, in 3 Volumes. Harper and Row, 1979.

Furnish, Dale B. "The Hierarchy of Peruvian Laws: Context for Law and Development." The American Journal of Comparative Law, vol. 19, no. 1, 1971, pp. 91-120. 
Gibbs, Meredith. "The Right to Development and Indigenous Peoples: Lessons from New Zealand." World Development, vol. 33, no. 8 , 2005, pp. 1365-78.

Gonzales, Tirso. "An Indigenous Autonomous Community-Based Model for Knowledge Production in the Peruvian Andes." Latin American and Caribbean Ethnic Studies, vol. 10, no.1, 2015, pp. 107-133.

Gonzalez, Maria, and Tirso Gonzales. "From Colonial Encounter to Decolonizing Encounters. Culture and Nature seen from the Andean Cosmovision of Ever: The Nurturance of Life as Whole." Nature and Culture. Routledge, 2010, pp. 101-120.

Holt Giménez, Eric, and Annie Shattuck. "Food Crises, Food Regimes and Food Movements: Rumblings of Reform or Tides of Transformation?" The Journal of Peasant Studies, vol. 38, no. 1, 2011, pp. 109-144.

Huambachano, Mariaelena. "Business and Sustainability: The Camisea Project in the Peruvian Amazon Basin. Corporate Social Responsibility and Sustainability." Emerging Trends in Developing Economies: Critical Studies on Corporate Responsibility, Governance and Sustainability, edited by Gabriel Eweje, Emerald Group Publishing, 2014, pp. 215-240.

-_---_. "Enacting Food Sovereignty in Aotearoa New Zealand and Peru: Revitalizing Indigenous Knowledge, Food Practices and Ecological Philosophies." Journal of Agroecology and Sustainable Food Systems, vol. 42, no. 9, 2018, pp. 1003-28.

------. Through an Indigenous Lens, Food Security is Food Sovereignty: Case Studies of Maori People of Aotearoa and Andean People of Peru. 2017. University of Auckland, PhD dissertation.

Hoover, Elizabeth. "You can't Say You're Sovereign if You can't Feed Yourself": Defining and Enacting Food Sovereignty in American Indian Community Gardening. American Indian Culture and Research Journal, vol. 5, no. 3, 1994, pp. 127-35.

International Panel of Experts on Sustainable Food Systems. From Uniformity to Diversity: a Paradigm Shift from Industrial Agriculture to Diversified Agroecological Systems. 2016, www.ipes-food. org/_img/upload/files/UniformityToDiversity_FULL.pdf.

Kovach, Margaret. Indigenous Methodologies: Characteristics, Conversations, and Contexts. University of Toronto, 2010. 
Kuhnlein, Harriet V., et al., editors. Indigenous Peoples' Food Systems and Well-being: Interventions and Policies for Healthy Communities. Food and Agriculture Organization of the United Nations (FAO). 2013, www.fao.org/3/a-i3144e.pdf.

La Vía Campesina. The Global Struggle for Peasants' Seeds: a Struggle for our Future. Grain. 22 November 2013, www.grain.org/ bulletin_board/entries/4836-the-global-struggle-for-peasants-seeds-a-struggle-for-our-future.

------. Proceedings from the II International Conferencia of the Via Campesina. NCOS Publications, 1996.

LaDuke, Winona. All Our Relations: Native Struggles for Land and Life. Haymarket Books, 2016.

------. "Traditional Ecological Knowledge and Environmental Futures." Journal of International Environment and Policy, vol. 5, 1994, pp. 127-35.

Lajo, Javier. "Sumaq Kawsay-ninchik o Nuestro Vivir Bien." Argenpress Cultural, 27 March 2010. www.cultural.argenpress.info/2010/03/ sumaq-kawsay-ninchik-o-nuestro-vivir.html.

Marglin, Frédérique Apffel. "Paper: Development or Decolonization in the Andes?" Futures, vol. 27, no.8, Oct. 1995, pp. 869-82.

Maxwell, Simon. "Food Security: A Post-Modern Perspective." Food Policy, vol. 21, no. 2, May 1996, pp. 155-70.

Mayer, Enrique. The Articulated Peasant: Household Economies

Indigenous

Social Movements in the Americas in the Andes. Routledge, 2018.

McGregor, Deborah. "Coming Full Circle: Indigenous Knowledge, Environment, and our Future." The American Indian Quarterly, vol. 28, no. 3, 2004, pp 385-410.

------. "Coming Full Circle: Indigenous Knowledge, Environment, and our Future." The American Indian Quarterly, vol. 28, no. 3-4, Summer/Fall 2004, pp 385-410.

McMichael, Philip. "A Food Regime Analysis of the 'world Food Crisis." Agriculture and Human Values, vol. 26, no. 4, 2009, p. 281.

------. "A Food Regime Genealogy." The Journal of Peasant Studies, vol. 36, no. 1, Dec. 2009, pp 139-69.

Paarlberg, Robert. Food Politics: What Everyone Needs to Know. Oxford UP, 2013. 
Pierotti, Raymond, and Daniel Wildcat. "Traditional Ecological Knowledge: The Third Alternative (Commentary)." Ecological Applications, vol. 10, no. 5, 2000, pp 1333-40.

Pihama, Leonie, Fiona Cram, and Sheila Walker. "Creating Methodological Space: A Literature Review of Kaupapa Maori Research." Canadian Journal of Native Education, vol. 26, no. 1, 2002, pp. 30-43.

Rostworowski de Diez Canseco, M. Historia Del Tahuantinsuyo. Lima: IEP/ PromPerú, 2003.

Shiva, Vandana. Earth Democracy: Justice, Sustainability and Peace. Zed Books, 2016.

Smith, Linda Tuhiwai. Decolonising Methodologies: Research and Indigenous Peoples. University of Otago, 1999.

Timmer, C. Peter. Food Security and Scarcity: Why Ending Hunger is so Hard. University of Pennsylvania Press, 2015.

United Nations Department of Economic and Social Affairs (UNDESA). United Nations Declaration on The Rights of Indigenous Peoples. 13 September 2007, www.un.org/development/desa/ indigenouspeoples/wpcontent/uploads/sites/19/2018/11/ UNDRIP_E_web.pdf .

United Nations Food and Agriculture Organization (FAO). Rome Declaration on World Food Security. 13 Nov. 1996, www.fao.org/ docrep/003/w3613e/w3613e00.htm.

Whyte, Kyle. "Food Justice and Collective Food Relations." The Ethics of Food: An Introductory Textbook, edited by A. Barnhill, M. Budolfson, and T. Doggett, Oxford UP, 2015, pp. 1-18.

------. "Food Sovereignty, Justice and Indigenous Peoples: An Essay on Settler Colonialism and Collective Continuance." Oxford Handbook on Food Ethics. Eds. A. Barnhill, T. Doggett, and A. Egan. New York: NYC: Oxford University Press, 2016. 1-21.

Wilson, Shawn. "Progressing Toward an Indigenous Research Paradigm in Canada and Australia." Canadian Journal of Native Education, vol. 27, no. 2, 2003, pp 161-78.

Wittman, Hannah, Nettie Wiebe, and Annette Aurelie Desmarais. Food Sovereignty: Reconnecting Food, Nature o Community, Fernwood, 2010. 
